\title{
Indonesia: Stratified health the norm
}

W

hen Irsan Nasution, a bus driver in the Indonesia capital of Jakarta, fell off a roof and severely injured his back and wrists two years ago, he knew he was lucky to have survived. But when he got to a newly opened private hospital in his neighbourhood in the Indonesian capital, physicians told him treatment would cost the equivalent of US\$7000, or about a year's income.

Unable to pay, and unable to work for almost a year, Nasution instead paid roughly US\$600 for therapies from an unlicensed traditional healer in a rural village in which he'd lived as a child.

The outcome?

Far from satisfactory. "I'm back at work now," Nasution says, while grimacing and easing himself gingerly back into the driver's seat of a bus. "But I'm beginning to doubt the pain in my back and wrists will ever stop."

It's not the first time Nasution had encountered intimidating medical bills in a private hospital. He'd racked up bills totalling US\$1400 during the birth of his two children, now aged 8 and 12. "I even had to pay extra to get receipts for the medicine the doctors used," he laments. In both instances, the children were born in private hospitals because, although the government of Indonesia passed laws in 2004, 2009 and 2011 to extend access to universal health care, the legislation was either unimplemented or highly restrictive.

As it stands, it only applies to the very poor, (i.e., those earning less than US\$27 per month).

"I'm considered too wealthy to deserve access to free public health care," Nasution says bitterly. "Yet I can't afford private care if anything catastrophic happens."

Nasution's predicament is far from unique.

Only about $30 \%$ of Indonesia's population of 248 million are actually entitled to government-subsidized care, says Dr. Untung Suseno Sutarjo, senior

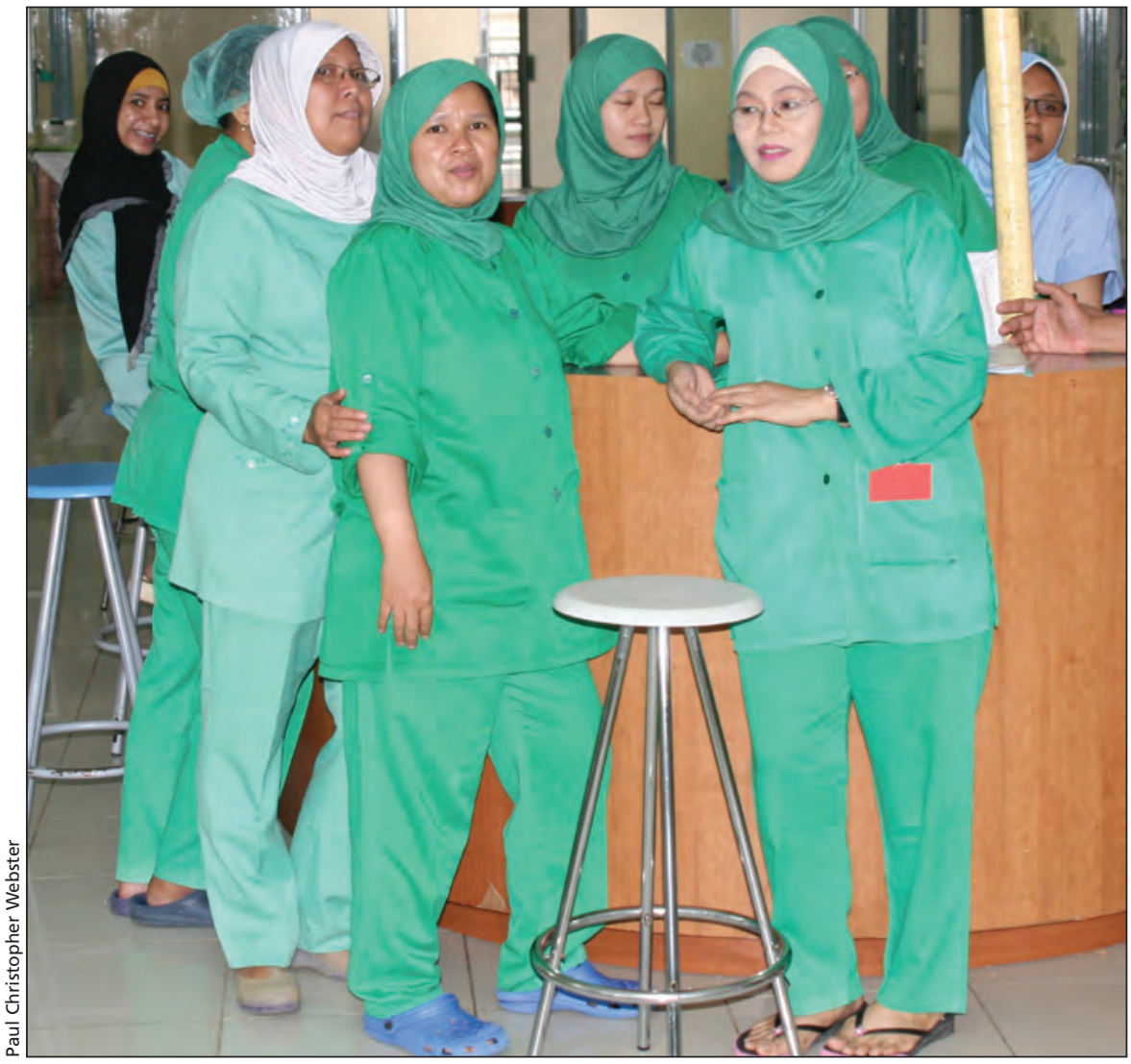

Health care workers at Budi Kemaliaan Hospital in Jakarta, Indonesia.

advisor on health financing to the Indonesian Ministry of Health.

With only $25 \%$ of the population able to afford private health care out-ofpocket or through private health insurance, Sutarjo estimates that leaves $45 \%$ of the population to fend for themselves. "Our constitution says the government should be responsible for managing social security, and the laws compel the government to create universal access to health care," he says. "But I don't think the government can afford to create a single-tier, universal access public system. What we have now is a class system in the wards where the government subsidizes third-class care for the poor. Meanwhile, the rich don't want to be in the same wards as the poor."

The failure to fashion a universal system guaranteeing access to public health care, Sutarjo says, is largely a function of a 1999 law requiring the federal government to surrender control over health administration and financing to regional authorities. As a result of the legislation, the federal government slashed health spending and relaxed its control over the health sector, which encouraged the construction of hundreds of private hospitals and opened the door for numerous competing private health insurance schemes.

Initially, the private industry targeted wealthy patients willing to pay to avoid treatment in dilapidated public facilities, Sutarjo says.

But even that is changing as the government expands universal care for the poor, he adds. "Usually, the private sector only caters to the rich. But now, the private sector is building new hospitals to care for the poor. This is a new phenomenon for us. But they 
want the guaranteed government payments. And they are also asking for higher payments, which we will probably give them."

Achieving universal access is proving problematic, says Dr. Laksono Trisnantoro, director of the Centre for Health Service Management and vice director of the PhD program at the Gadjah Mada University School of Medicine in the eastern city of Yogyakarta.

Part of the reason for that is cultural, he notes. "The idea of universal access and equality has never really taken root. We're used to a stratified system."

As problematic are the challenges of geography, he adds. Extending coverage into remote areas of Indonesia's 15000 islands is a mind-boggling task but "we desperately have to do this. Otherwise universal coverage can’t work."
To do that, the government will have to open its vaults, says Dr. Zaenal Abidin, president-elect of the 100 000member Indonesia Medical Association. "You attract more ants by giving more sugar," he notes, while adding that the decentralized nature of the Indonesian nation "has blocked the government's ability to solve this problem."

Abidin also questions the depth of the federal government's commitment to universality, noting that it has not yet met financial obligations first stipulated in the 2004 legislation. It's created a situation in which deficiencies are the norm, he says, noting that about $40 \%$ of district hospitals, for example, do not have an obstetrician.

Purwo Santoso, director of the Department of Politics and Government at Gadjah Mada University, argues that growing reliance on private delivery does not mesh with the commitment to universal access. Decentralization and privatization turned Indonesia public health facilities into "profit centres," in which care for the poor is diminished, he concluded in a study (Health Policy 2006:77[3]:247-59. Epub 2005).

"The private health care suppliers simply don't operate in the rural areas where there is the greatest need," Santoso says. "So it's questionable whether the vision of universal access can be achieved. It seems probable that you can only guarantee universal access if you make the government run these services." - Paul Christopher Webster, Jakarta, Indonesia

CMAJ 2013. DOI:10.1503/cmaj.109-4352 